\title{
Evidence-based strategies for the minimally invasive treatment of carious lesions: Review of the literature
}

\author{
Rodrigo A. Giacaman ${ }^{1, A, C, D, F}$, Cecilia Muñoz-Sandoval ${ }^{1, B, D, F}$, Klaus W. Neuhaus ${ }^{2, E, F}$, Margherita Fontana ${ }^{3, E, F}$, Renata Chałas ${ }^{4, C, E, F}$ \\ ${ }^{1}$ Cariology Unit, Department of Oral Rehabilitation and Interdisciplinary Excellence Research Program on Healthy Aging (PIEl-ES), University of Talca, Chile \\ 2 Department of Preventive, Restorative and Pediatric Dentistry, School of Dental Medicine, University of Bern, Switzerland \\ ${ }^{3}$ Department of Cariology, Restorative Sciences and Endodontics, School of Dentistry, University of Michigan, Ann Arbor, USA \\ ${ }^{4}$ Department of Conservative Dentistry and Endodontics, Medical University of Lublin, Poland \\ A - research concept and design; $\mathrm{B}$ - collection and/or assembly of data; $\mathrm{C}$ - data analysis and interpretation; \\ $D$ - writing the article; $E$ - critical revision of the article; $F$ - final approval of the article
}

Address for correspondence

Renata Chałas

E-mail: renata.chalas@umlub.pl

\section{Funding sources}

These investigations have been funded by the Chilean Government Grant Fondecyt No.: 1140623 to Rodrigo A. Giacaman. This manuscript was submitted in partial fullfillment of the requirements for the Graduate Program in Pediatric Dentistry by Cecilia Muñoz-Sandoval at the University of Talca, Chile.

\section{Conflict of interest}

None declared

Received on April 11, 2017

Reviewed on June 18, 2017

Accepted on September 15, 2017

\begin{abstract}
Resulting in a high economic and biological cost, the traditional therapeutic approach to carious lesion management is still largely restorative. Minimally invasive (MI) treatment offers an attractive alternative to managing carious lesions in a more conservative and effective manner, resulting in enhanced preservation of tooth structure. The aim of this review was to summarize the evidence behind several MI alternatives for carious lesion management, including the use of sealants, infiltration, atraumatic restorative treatment (ART), and selective carious tissue removal (e.g., indirect pulp capping, stepwise removal, or selective removal to soft dentine). Relevant literature was screened, and articles reporting randomized controlled trials or systematic reviews of strategies to manage non-cavitated or cavitated carious lesions in adults and children were included. Fifty six articles met the inclusion criteria. For non-cavitated lesions, the use of sealants is supported by strong evidence, while the evidence for infiltration of proximal lesions is moderate. For deep cavitated lesions, selective removal to soft dentin and/or stepwise excavation is supported by strong evidence. The use of the ART technique to restore cavitated lesions is also supported by strong evidence as a suitable strategy that has been used extensively in the literature concerning non-dental settings. Preservation of tooth structure through the use of Ml treatment for both non-cavitated and cavitated lesions is supported by moderatestrong evidence, which supports the paradigm shift towards routine use of more conservative strategies in the treatment of carious lesions.
\end{abstract}

Key words: dental caries, minimally invasive treatment, partial caries removal, stepwise technique, atraumatic restorative treatment

DOI

10.17219/acem/77022

\section{Copyright}

Copyright by Author(s)

This is an article distributed under the terms of the

Creative Commons Attribution Non-Commercial License

(http://creativecommons.org/licenses/by-nc-nd/4.0/) 


\section{Introduction}

Dental caries is a sugar and biofilm dependent disease, where frequent sugars exposure leads to an ecologic imbalance in the environment of the dental biofilm. The ecological shift turns the otherwise commensal bacteria to a cariogenic condition with increased production of demineralizing acids and the subsequent carious lesion formation on the dental hard tissues. Minimally invasive (MI) treatment of dental caries is an approach that considers handling carious lesions with conservative techniques to preserve maximum tooth structure. ${ }^{1}$ The MI treatment is also a conceptual framework that ranges from primary prevention and management of the caries disease process, to the management of carious lesions by surgical and non-surgical means. Besides considering the type of lesion, the selection of a treatment technique based on the MI philosophy must be the result of a personalized risk analysis of each patient. ${ }^{2}$ Personalized medicine is being increasingly used in medicine and is expected to be included within the dental field, as well. In fact, caries risk-based care is an essential component of targeted health care delivery and is of paramount importance within the context of high healthcare costs and resource constraints. ${ }^{3}$

Successful caries management for an individual patient must include strategies to manage the caries disease process at the patient level, as well as strategies to manage the existing lesions at the tooth level. ${ }^{4,5}$ Yet, there is a tendency in many places, either private practice or public oral care services, to prioritize caries treatment primarily by means of traditional operative dentistry. In many countries, financial and/or reimbursement models for caries management, either in the private or public domain, are built primarily around traditional "restorative" procedures for the management of cavitated caries lesions. Reimbursement for more conservative strategies, either at the patient or tooth level, is much more difficult and varied, which hinders implementation. New studies show that when appropriately trained in MI techniques, dentists and patients have a favorable opinion, and in many instances they prefer more conservative therapies for caries management. ${ }^{6}$

Many strategies for the MI management of caries lesions have been developed and evaluated in the literature throughout the last 50 years. For example, in the early $1970 \mathrm{~s}$ silver diamine fluoride was developed in Japan as a conservative alternative for the management of cavitated lesions without the need of tissue removal or subsequent restoration. ${ }^{7}$ This topic is not reviewed here, as this is a noninvasive approach, but the reader is referred to an updated review. ${ }^{8}$ The development of dental sealants opened the door to prevention and conservative management of noncavitated lesions. ${ }^{9}$ Over time, other techniques have been developed having the same MI-based philosophy. For example, the idea of a "Preventive Resin Restoration" was first reported in 1977 as a way to call attention to a shift in philosophy, away from the traditional GV Black's “extension for prevention", to a more conservative approach, made possible with the use of resin-composite materials for the management of cavitated carious lesions. ${ }^{4,5}$ Atraumatic restorative treatment (ART) was developed as an alternative treatment for the management of cavitated lesions, in which demineralized tissue is removed with hand instruments only, and thus pain is kept to a minimum. Originally, ART was developed for use in rural developing countries, because it does not require local anesthesia or electricity, but more recently, ART has become increasingly accepted in developed countries because of its "atraumatic" approach in relation to stress and pain, and because it conserves tooth structure. ${ }^{10}$ More recently, infiltration was developed as an alternative to the management of interproximal non-cavitated carious lesions. ${ }^{11}$ Furthermore, regarding caries removal prior to restorative procedures, current recommendations focus on preserving the tooth structure, and guidelines have evolved to currently include, for example, that in deep cavitated carious lesions, selective removal to soft dentine and/ or stepwise removal should be performed to maintain the health of the pulp. ${ }^{5}$

The aim of this review is to examine the scientific evidence behind some of the most commonly MI alternatives for caries lesion management used today, including sealants, infiltration, ART and selective and/or stepwise removal for the management of deep carious lesions.

\section{Methods}

Relevant literature was retrieved by searching several databases, including MEDLINE (EBSCO), ProQuest, Cochrane Library (Wiley), and PubMed. The following search terms were used either alone or in combination: "minimally invasive treatment", "caries management", "partial caries removal", "stepwise technique", "incomplete caries removal", "atraumatic restorative treatment", "indirect pulp treatment", "resin infiltration", "proximal sealing" and "caries arrest". Only studies published between 1966 and 2016 in English language were considered.

To be included, studies must be conducted in human subjects, including randomized controlled trials (RCT), systematic reviews, and meta-analyses. References used in the cited systematic reviews were included by means of a manual search. Studies that considered surrogate outcomes, such as bacterial counts or marginal staining, were not included, leaving only those that reported carious lesion progression, restoration survival, pulp exposure, or symptoms derived from caries activity. A total of 297 articles dealing with the subject were found, but only 56 articles fulfilled the inclusion criteria and were finally included in this revision of the literature. All the articles were searched by one of the authors (CMS) and then revised by a second researcher to confirm the pertinence of the selection criteria (RAG). When there were discrepancies in article selection, discussions were undertaken until an agreement was reached. 


\section{Results and discussion}

Despite a reported decrease in prevalence, dental caries remains a major public health problem worldwide, as it remains the leading cause of tooth loss and the most common human condition, affecting $35 \%$ of the world population at all ages. ${ }^{12}$ Unfortunately, the disease is not being treated in most developing countries due to the high economic and social costs associated with its treatment by conventional restorative-focused methods. ${ }^{13}$ New costeffective strategies to treat the disease and its resulting caries lesions are, therefore, required. In this context, MI treatment allows increased access with reduced cost and complexity. By using targeted disease prevention and management, based on the best available evidence, and using simpler techniques in the management of carious lesions, a better distribution of resources may be implemented directing them to the population groups with the highest caries needs.

\section{Carious lesion diagnosis and minimally invasive therapies}

Before discussing the use of MI strategies for caries management, a brief mention about lesion detection and monitoring is needed. Despite the undeniable usefulness of WHO criteria in portraying the epidemiological burden of the disease worldwide for many years, more inclusive methods for caries detection and diagnosis have been established during the last few decades. ${ }^{14}$ The WHO criteria count caries only when there is a cavitation in dentine, but they disregard less extensive lesions. Thus, treatment decisions based primarily on WHO criteria are mostly restorative. Hence, the need for improved diagnostic accuracy has resulted in the development of further refined caries detection systems. Currently, perhaps the most internationally recognized and used visual caries detection system, including clinical research, is the International Caries Detection and Assessment System (ICDAS). ${ }^{15}$ The main aim of the ICDAS methodology is to detect and classify the small variations in visual signs that occur at the tooth level throughout the progression of caries disease. Besides the extent of the disease, the activity status of the lesions must also be taken into account, as different clinical behavior is expected for 2 lesions of the same ICDAS code, but different activity status. Nyvad's activity criteria are a reasonable way to assess lesion activity, which permits the implementation of MI therapies. ${ }^{16}$

\section{Non-invasive management of non-cavitated lesions}

The treatment of choice for non-cavitated lesions should be based on the diagnosis of the lesions, both its extension and the status of active or inactive, the caries risk at the patient level, and the best evidence available to support the treatment decision. In the case of active non-cavitated lesions (ICDAS codes 1 and 2), it is essential to ensure that any selected treatment arrests progression, thus preventing cavitation. Since these lesions maintain tooth surface integrity, at least at the clinical level, it is possible to induce remineralization to revert the process. ${ }^{2}$ Although this review focuses on sealants and infiltration, this approach must be taken in the context of proper exposure to fluoride and dietary counselling. The effect of non-invasive treatment relies on an ecological change in the oral environment that will favor remineralization. ${ }^{17} \mathrm{With}$ vast evidence available, fluoride is the most effective caries preventive measure. ${ }^{18}$ Topical fluorides in the form of toothpastes, mouthwashes, gels, and varnishes are effective interventions in preventing dental caries in children and adolescents. ${ }^{19}$ Although most of the available evidence derives from fluoride-based products, other substances have also been proposed as remineralizing agents, such as casein phosphopeptideamorphous calcium phosphate (CPP-ACP), but clinical evidence is still limited and prevents us from drawing definitive conclusions. ${ }^{20}$

\section{Sealing and infiltration; minimally invasive treatment of non-cavitated carious lesions}

Along with the strong evidence on the use of sealants to prevent dental caries in children at different risk levels, this simple dental procedure is also effective in halting lesion progression. ${ }^{10,21}$ Sealant-treated teeth show a mean annual progression of non-cavitated lesions of $2.6 \%$ compared to $12.6 \%$ for unsealed lesions. ${ }^{22}$ Robust evidence indicates that caries lesions do not progress under well retained sealants. ${ }^{23}$ In a further step, a recent study in a high-caries population in the US showed that even caries lesions without frank cavitation (ICDAS codes 1-4) showed very small progression rate at a follow-up of 44 months. ${ }^{24}$ Sealants impair nutrient acquisition from the oral environment by invading bacteria, which results in a reduction in the number and viability of microorganisms under the material over time, thus arresting the lesion. ${ }^{25}$ In the case of non-cavitated proximal lesions, the use of resin sealants has shown to be more effective in reducing progression than the use of dental floss. ${ }^{26} \mathrm{Re}-$ cently, a new system of lesion infiltration has been developed to seal proximal lesions in a tri-dimensional fashion using a low-viscosity light-curing resin. ${ }^{11}$ A clinical study of non-cavitated interproximal lesions radiographically extending into the inner half of the enamel (E2) or in the outer third of the dentine (D1) showed a progression rate of $7 \%$ in the infiltrated lesions compared to $37 \%$ in untreated lesions. ${ }^{27}$ Another randomized controlled clinical trial showed a progression rate of $4 \%$ in infiltrated lesions 
compared to $42 \%$ in untreated lesions at a 3-year follow-up. ${ }^{11}$ Unlike occlusal lesions, it is not possible to conclude that sealing or infiltrating proximal lesions is superior to controlling lesions by stabilizing the oral ecosystem with good hygiene, dietary control and appropriate fluoride use. ${ }^{28}$

Caries lesions may be treated using resin or glass ionomer (GI) sealants. It is uncertain whether one type of sealant performs better than the other. It has been suggested that conventional GI sealants used as therapy for noncavitated occlusal lesions may be not effective enough to prevent lesion progression. ${ }^{29}$ In contrast, one clinical trial showed that non-cavitated occlusal carious lesions sealed with a high-viscosity GI sealant in a non-clinical setting was effective in avoiding lesion progression over a period of 6 years. ${ }^{30}$ It has been claimed that resin-based sealants are highly sensitive technique, requiring strict moisture control during placement with the use of rubber dam. This technical requirement is not always easy to achieve in children. Under those conditions, the hydrophilic properties of GI make them an attractive alternative material, but still with limited evidence.

In summary, there is consistent and strong good quality evidence to support non-invasive or MI treatment of noncavitated lesions using sealants. Infiltration of proximal lesions shows consistent positive results for management of non-cavitated caries lesions, but the amount of good quality studies is still limited (moderate evidence). Individual risk assessment and a comprehensive clinical judgment should be considered when choosing the most appropriate therapeutic procedure for these caries lesions.

\section{Minimally invasive therapy for cavitated carious lesions}

The management of deep dentine carious lesions imposes several challenges for the clinician. Besides the technical complexity in removing compromised tissues in more extensive lesions, these procedures may result in pulp exposure and loss of vitality, which implies the need for even more complex restorative treatments. In an effort to preserve tooth structure as much as possible and prevent irreversible pulp damage, conservative techniques have been proposed for carious dentine removal. ${ }^{4-5,31}$ Unlike the traditional and, unfortunately, still more popular complete excavation method or nonselective removal to hard dentine, techniques for carious dentine removal based on the MI philosophy are similar in that they are conservative and aimed at removing only a portion of the compromised tissues. ${ }^{4,32}$ There are several techniques for the MI approach to deep dentine caries treatment (selective removal of carious tissue, stepwise removal or nonselective removal to hard dentine), ${ }^{4,5}$ but only techniques with broader support of external evidence will be discussed; atraumatic restorative treatment (ART), stepwise removal (SW), and selective removal to soft dentine (also known as partial caries removal) (Table 1).

\section{Atraumatic restorative treatment}

Atraumatic restorative treatment (ART) is the MI treatment technique aimed at arresting caries progression of extensive cavitated lesions through the partial removal of the involved tissues with hand instruments and their subsequent restoration with high viscosity GI. ${ }^{10}$ Several studies with ART suggest that this therapy has a comparable success rate than traditional complete removal technique and the subsequent restoration with composite resin or amalgam. ${ }^{33,34} \mathrm{~A}$ meta-analysis on the survival of ART restorations found survival rates on one surface and multiple surfaces in primary teeth for more than 2 years of $93 \%$ and $62 \%$, respectively. ${ }^{35}$ In permanent teeth, ART restorations on one surface exhibited survival at 3 and 5 years of $85 \%$ and $80 \%$, respectively. Similarly, another systematic review showed a survival of ART restorations on one surface of $95 \%$ and $86 \%$ at 1 and 3 years, respectively and of $72 \%$ at 6 years after placement. ${ }^{36}$ The available evidence suggests that ART is a scientifically-supported MI treatment. Since this technique allows treatment in non-clinical settings at low cost, it may enhance access to care for the community, especially in developing countries. Importantly, ART restorations on multiple surfaces appear to be less successful and would require more complex restorations to ensure greater longevity. ${ }^{37}$

\section{Stepwise removal}

Besides ART, other MI therapies have been devised for deep dentine caries, such as indirect pulp capping (IPC), excavation in 2 stages, or SW excavation or removal, and more recently, the partial caries removal technique, or selective removal to soft or to firm dentine (Table 1). ${ }^{38,39,40,4}$ IPC is a form of selective caries removal which involves leaving a thin layer of demineralized tissue over the pulp which is covered by a protective liner. Final restoration is made in the same session. The material used for pulp protection does not appear to influence treatment success, according to a Cochrane review. ${ }^{41}$ Lesion arrest was reported in primary teeth with a success rate of $78 \%$ at 4 years, with no difference between an adhesive system and calcium hydroxide used as liners. ${ }^{42}$

The main disadvantage of IPC is that it involves procedures that are quite close to the pulp, thereby increasing the chances of pulp exposure. A less invasive approach for lesion removal without reaching the proximity of the pulp, is the SW technique, which involves lesion removal in 2 stages. ${ }^{43,44}$ Stepwise removal technique consists of a first step involving partial carious tissue removal, leaving soft carious tissue on the pulpal cavity floor of a deep carious lesion, in a vital tooth. Teeth are temporarily restored for a period of up to 12 months. A re-entry is then necessary to remove the carious tissue to firm dentine, followed by a permanent final restoration. ${ }^{31}$ During the temporary sealing, the soft carious dentine, which was intentionally 
Table 1. Evaluation of the effectiveness of the removal of cavitated carious lesions with minimally invasive techniques; stepwise (SW) and selective removal to soft dentine (SRSD) or partial caries removal

\begin{tabular}{|c|c|c|c|c|c|c|}
\hline Source & Technique & Control & Number of evaluated teeth & $\begin{array}{l}\text { Age } \\
\text { [years] }\end{array}$ & $\begin{array}{l}\text { Follow-up } \\
\text { [years] }\end{array}$ & Main results \\
\hline $\begin{array}{l}\text { (Magnusson and } \\
\text { Sundell, 1977) }\end{array}$ & stepwise & $\begin{array}{l}\text { nonselective to } \\
\text { hard dentine } \\
\text { (complete removal) }\end{array}$ & $\begin{array}{l}110 \text { primary teeth (55 SW } \\
\text { and } 55 \text { complete removal) }\end{array}$ & $5-10$ & $\begin{array}{l}\text { no follow- } \\
\text { up }\end{array}$ & $\begin{array}{l}\text { pulp exposure: stepwise } 11 \% \\
\text { vs complete removal } 53 \%\end{array}$ \\
\hline $\begin{array}{l}\text { (Heinric, Kneist, } \\
\text { and Künzel, } \\
1991)^{46}\end{array}$ & stepwise & $\begin{array}{l}\text { nonselective to } \\
\text { hard dentine } \\
\text { (complete removal) }\end{array}$ & $\begin{array}{l}125 \text { primary teeth ( } 52 \mathrm{SW} \\
\text { and } 52 \text { complete removal) }\end{array}$ & $6-7$ & 1.3 & $\begin{array}{l}\text { pulp exposure: stepwise 15\% } \\
\text { vs complete removal 31\%; } \\
\text { pulp symptoms: stepwise } 8 \% \\
\text { vs complete removal 18\% }\end{array}$ \\
\hline $\begin{array}{l}\text { (Leksell et al., } \\
\text { 1996) }\end{array}$ & stepwise & $\begin{array}{l}\text { nonselective to } \\
\text { hard dentine } \\
\text { (complete removal) }\end{array}$ & 134 permanent teeth & $6-16$ & 3 & $\begin{array}{l}\text { pulp exposure: stepwise: } 17.5 \% \\
\text { vs complete removal } 40 \%\end{array}$ \\
\hline $\begin{array}{l}\text { (Maltz et al., } \\
2007)^{54}\end{array}$ & SRSD & ---- & 32 permanent teeth & $12-23$ & 3.75 & $\begin{array}{l}\text { 6-7 months: } 31 \text { of } 32 \text { without } \\
\text { symptoms: } 97 \% \text {; } \\
\text { 14-18 months: } 22 \text { of } 22 \text { without } \\
\text { symptoms: } 100 \% \text {; } \\
\text { 36-45 months: } 24 \text { of } 24 \text { without } \\
\text { symptoms: } 100 \% \text {; } \\
\text { between } 14-1836-45 \text { months: } \\
2 \text { patients restoration and } \\
\text { endodontics }\end{array}$ \\
\hline $\begin{array}{l}\text { (Bjørndal et al., } \\
2010)^{44}\end{array}$ & stepwise & $\begin{array}{l}\text { nonselective to } \\
\text { hard dentine } \\
\text { (complete removal) }\end{array}$ & $\begin{array}{l}314 \text { permanent teeth } \\
\text { (156 SW and } 158 \text { control) }\end{array}$ & $>18$ & 1 & $\begin{array}{l}\text { pulp exposure: stepwise } 17.5 \% \\
\text { vs complete removal } 28.9 \%\end{array}$ \\
\hline $\begin{array}{l}\text { (Alves et al., } \\
2010)^{55}\end{array}$ & SRSD & ---- & 32 permanent teeth & $12-13$ & 10 & $\begin{array}{l}92.3 \% \text { no change or decrease in depth; } \\
76.9 \% \text { tertiary dentin formation }\end{array}$ \\
\hline $\begin{array}{l}\text { (Orhan, Oz, and } \\
\text { Orhan, 2010) }\end{array}$ & $\begin{array}{l}\text { indirect } \\
\text { pulp } \\
\text { capping, } \\
\text { SRSD }\end{array}$ & $\begin{array}{l}\text { nonselective to } \\
\text { hard dentine } \\
\text { (complete removal) }\end{array}$ & $\begin{array}{l}154 \\
\text { (94 primary and } 60 \\
\text { permanent) }\end{array}$ & $4-15$ & 1 & $\begin{array}{l}\text { pulp exposure: indirect pulp capping: } \\
\qquad 8 \% ; \\
\text { SRSD: } 6 \% \text {; complete removal: } 22 \%\end{array}$ \\
\hline $\begin{array}{l}\text { (Maltz et al., } \\
2012)^{58}\end{array}$ & SRSD & stepwise & $\begin{array}{l}299 \text { permanent teeth (152 } \\
\text { partial caries removal and } \\
147 \text { SW) }\end{array}$ & $6-53$ & 3 & pulp vitality: SRSD 91\% vs SW 69\% \\
\hline $\begin{array}{l}\text { (Maltz et al., } \\
2012)^{52}\end{array}$ & SRSD & stepwise & $\begin{array}{l}299 \text { permanent teeth }(153 \\
\text { partial caries removal and } \\
146 \text { SW) }\end{array}$ & $6-53$ & 1.5 & pulp vitality: SRSD 99\% vs $89 \%$ SW \\
\hline $\begin{array}{l}\text { (Franzon et al., } \\
2014)^{50}\end{array}$ & SRSD & $\begin{array}{l}\text { nonselective to } \\
\text { hard dentine } \\
\text { (complete removal) }\end{array}$ & $\begin{array}{l}120 \text { primary teeth ( } 66 \text { partial } \\
\text { caries removal and } 54 \\
\text { complete removal) }\end{array}$ & $3-8$ & 2 & $\begin{array}{l}\text { pulp exposure: } 2 \% \text { partial caries } \\
\text { removal vs } 27.5 \% \text { complete removal; } \\
\text { pulp vitality: } 92 \% \text { partial caries } \\
\text { removal vs } 96 \% \text { complete removal }\end{array}$ \\
\hline $\begin{array}{l}\text { (Oliveira et al., } \\
2006)^{56}\end{array}$ & $\begin{array}{l}\text { partial caries } \\
\text { removal }\end{array}$ & ---- & 32 permanent teeth & $12-23$ & 1.5 & $\begin{array}{l}100 \% \text { no clinical symptoms and } \\
\text { positive cold test }\end{array}$ \\
\hline
\end{tabular}

left remaining, becomes harder and drier, both characteristics of inactive lesions, exhibiting a low level of bacterial infection. ${ }^{31}$ The objective of this procedure is to facilitate the physiological reaction of the pulp-dentine complex, including dentinal sclerosis and tertiary dentine formation. Thus, a 2 -step process ensures pulp protection by minimizing the risk of exposure. Several studies have indicated that SW is a highly successful procedure. ${ }^{45,46} \mathrm{~A}$ recent meta-analysis has revealed a $56 \%$ reduction in the incidence of pulp exposure in SW excavation compared to complete caries removal or non-selective to hard dentine, as it is the most recently agreed term. ${ }^{4,47}$ The main problems of the SW technique are the risk of pulp exposure during re-entry, the failure of the temporary restoration, and increased costs resulting from the 2 sessions that are required to complete treatment. Furthermore, it has been observed that one of the causes of failure is that some patients do not return for the final restoration due to the absence of symptoms. ${ }^{48}$

\section{Selective removal to soft dentine or partial caries removal}

As a way to improve the effectiveness of the SW and IPC techniques, it has been proposed that selective removal of the carious tissue to soft dentine in deep cavitated lesions, with vital teeth, be performed. ${ }^{49,50}$ A recently published consensus paper has named this procedure as selective removal to soft dentine, formerly known as partial caries removal. ${ }^{4}$ In this strategy the final restoration should be performed during the same session, completing 
the procedure in a single appointment. ${ }^{51,52}$ In fact, it has been suggested that re-entering the cavity after partial or selective removal in the SW technique is unnecessary. ${ }^{53}$ In the selective removal of soft dentine technique, selective removal to firm dentine from the lateral walls of the lesion is necessary, removing gently and without pressure only the most outer layer of softened dentine from the pulp wall with manual or rotary instrumentation, and placing the final restoration in the same session. ${ }^{54}$ A study that followed a cohort of patients treated with selective removal to soft dentine showed that 12 of 13 teeth with lesions remained unchanged for 10 years. ${ }^{55}$ Radiographic analysis showed tertiary dentine in $77 \%$ of cases. Likewise, another study checked the arrest of selective removal to soft dentinetreated lesions by radiographic follow-up with subtraction imaging techniques. ${ }^{56}$ The number of microorganisms was also reduced after sealing the cavity, reaching similar recovery levels to those found in nonselective to hard dentine or complete removal. ${ }^{57}$ Considering that selective removal to soft dentine is even more MI and conservative than IPC or SW, the risk of pulp exposure was expected to be even lower. Recently, a multicenter clinical study has evaluated the efficacy of selective removal to soft dentine and restoration in a single session compared to SW for the treatment of deep caries lesions. ${ }^{58}$ The results showed a success rate of $91 \%$ with selective removal to soft dentine compared with $69 \%$ for the SW technique. The accumulated evidence from clinical trials confirms that this is an appropriate and helpful MI approach to treat lesions in close proximity to the pulp (strong evidence), reducing the risk of exposure and postoperative symptoms compared with non-selective to hard dentine or complete removal. ${ }^{4}$ Additionally, this technique has a lower economic cost and lower long-term risk of pulp complications. ${ }^{46}$ The evidence supporting these MI procedures is still limited. Thus, further research is needed before more definitive conclusions can be drawn. ${ }^{59}$ In fact, a recently published meta-analysis states that the evidence remains insufficient to determine which technique is most effective for the management of deep dentine lesions and emphasizes the need for more studies to generate evidence. ${ }^{60}$

\section{Conclusions}

Minimally invasive techniques for carious lesion treatment reviewed here offer an attractive alternative for improving dental care coverage at the individual and the community level. It is important to remark that before making decisions on the therapies for the lesions, clinicians must evaluate caries risk at the patient level and also assess the lesions. Preventive measures must always be considered and implemented to control the onset of new lesions on unaffected tissues. After treating current lesions, a permanent follow-up regime must be implemented to reinforce prevention and to monitor lesions over time (Fig. 1).

The use of sealants as MI treatment for active noncavitated lesions is supported by strong evidence and it is, therefore, a reasonable strategy for the management of non-cavitated lesions at a very low cost. Sealants and infiltration appear to be effective alternatives for management on interproximal active carious lesions. The ability to treat non-cavitated lesions with even less expensive methods, such as tooth brushing with fluorides, remains

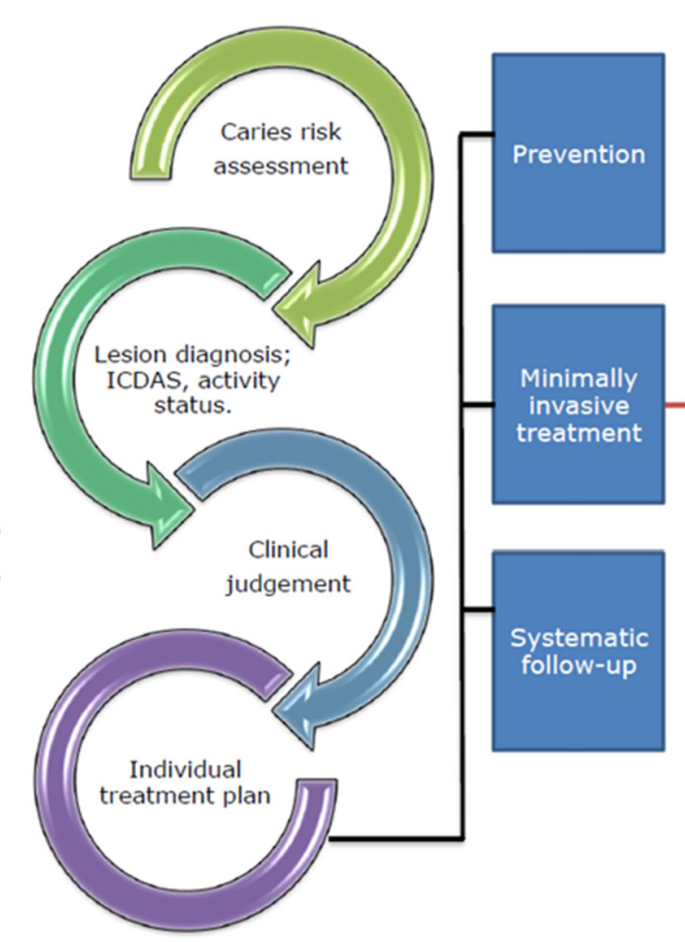

Fig. 1. Article content overview. Minimally invasive approach for caries lesion treatment requires different steps before making a therapeutic decision. Preventive strategies must be included in order to control the disease and to avoid the onset of new lesions. Depending on whether lesions are categorized as non- or cavitated, clinicians must choose among the different Ml techniques. As important as the treatment itself, patients must be incorporated into a systematic follow-up plan, with a preventive focus and lesions monitored over time 
a potential solution, but the studies in occlusal surfaces are still insufficient for their recommendation compared to sealants. Selective removal to soft dentine in cavitated deep dentine lesions allows fast and inexpensive procedures that generate very little discomfort to the patient, greatly reducing the possibility of pulp exposure and, consequently, the need for complex treatments. Evidence appears to support the idea that selective removal to soft dentine is a safe technique, although the need for further studies is suggested. Similarly, ART is a good alternative in situations where there is a need to provide care in communities lacking a traditional dental clinic. Minimally invasive treatment of both cavitated and non-cavitated carious lesions constitutes a rational strategy for the management of dental caries and should be encouraged at the public, private, and educational level in universities. Despite the obvious advantages of these techniques compared with the more traditional approaches, there is a natural resistance to change in many professionals. It is, therefore, necessary to confront the clinicians with the available evidence to engage them into a more MI treatment philosophy.

\section{References}

1. Tyas MJ, Anusavice KJ, Frencken JE, Mount GJ. Minimal intervention dentistry - a review. FDI Commission Project 1-97. Int Dent J. 2000;50(1):1-12.

2. Walsh LJ, Brostek AM. Minimum intervention dentistry principles and objectives. Aust Dent J. 2013;58(Suppl 1):3-16.

3. Fontana M. The clinical, environmental, and behavioral factors that foster early childhood caries: Evidence for caries risk assessment. Pediatr Dent. 2015;37(3):217-225.

4. Innes NP, Frencken JE, Bjorndal L, et al. Managing carious lesions: Consensus recommendations on terminology. Adv Dent Res. 2016; 28(2):49-57.

5. Schwendicke F, Frencken JE, Bjorndal L, et al. Managing carious lesions: Consensus recommendations on carious tissue removal. Adv Dent Res. 2016;28(2):58-67.

6. Santamaria RM, Innes NP, Machiulskiene V, Evans DJ, Alkilzy M, Splieth $\mathrm{CH}$. Acceptability of different caries management methods for primary molars in a RCT. Int J Paediatr Dent. 2015;25(1):9-17.

7. Yamaga R, Nishino M, Yoshida S, Yokomizo I. Diammine silver fluoride and its clinical application. J Osaka Univ Dent Sch. 1972;12:1-20.

8. Gao SS, Zhang S, Mei ML, Lo EC, Chu CH. Caries remineralisation and arresting effect in children by professionally applied fluoride treatment - a systematic review. BMC Oral Health. 2016;16(1):12. doi: 10.1186/s12903-016-0171-6

9. Ahovuo-Saloranta A, Forss H, Walsh T, et al. Sealants for preventing dental decay in the permanent teeth. Cochrane Database Syst Rev. 2013;(3):CD001830. doi: 10.1002/14651858.CD001830.pub4

10. Frencken JE, Leal SC, Navarro MF. Twenty-five-year atraumatic restorative treatment (ART) approach: A comprehensive overview. Clin Oral Investig. 2012;16(5):1337-1346.

11. Meyer-Lueckel H, Bitter K, Paris S. Randomized controlled clinical trial on proximal caries infiltration: Three-year follow-up. Caries Res. 2012;46(6):544-548

12. Kassebaum NJ, Bernabé E, Dahiya M, Bhandari B, Murray CJ, Marcenes W. Global burden of untreated caries: A systematic review and metaregression. J Dent Res. 2015;94(5):650-658.

13. Yee $R$, Sheiham $A$. The burden of restorative dental treatment for children in Third World countries. Int Dent J. 2002;52(1):1-9.

14. Petersen PE. The World Oral Health Report 2003: Continuous improvement of oral health in the $21^{\text {st }}$ century - the approach of the WHO Global Oral Health Programme. Comm Dent Oral Epidemiol. 2003;31(Suppl 1):3-23.
15. Ismail Al, Sohn W, Tellez M, et al. The International Caries Detection and Assessment System (ICDAS): An integrated system for measuring dental caries. Comm Dent Oral Epidemiol. 2007;35(3):170-178.

16. Nyvad B, Machiulskiene V, Baelum V. Reliability of a new caries diagnostic system differentiating between active and inactive caries lesions. Caries Res. 1999;33(4):252-260.

17. Marsh PD. Dental plaque as a microbial biofilm. Caries Res. 2004;38(3): 204-211.

18. Jones S, Burt BA, Petersen PE, Lennon MA. The effective use of fluorides in public health. Bull World Health Organ. 2005;83:670-676.

19. Marinho VC, Higgins JP, Logan S, Sheiham A. Fluoride varnishes for preventing dental caries in children and adolescents. Cochrane Database Syst Rev. 2002;(3):CD002279.

20. Fontana M. Enhancing Fluoride: Clinical Human Studies of Alternatives or Boosters for Caries Management. Caries Res. 2016;50,Suppl 1:22-37.

21. Ahovuo-Saloranta A, Hiiri A, Nordblad A, Worthington H, Mäkelä M. Pit and fissure sealants for preventing dental decay in the permanent teeth of children and adolescents. Cochrane Database Syst Rev. 2004;(3):CD001830. doi: 10.1002/14651858.CD002279

22. Griffin SO, Oong E, Kohn W, Vidakovic B, Gooch BF, Bader J; Group C.D.S.S. R.W. The effectiveness of sealants in managing caries lesions. J Dent Res. 2008;87(2):169-174.

23. Borges BC, de Souza Borges J, Braz R, Montes MA, de Assunção Pinheiro IV. Arrest of non-cavitated dentinal occlusal caries by sealing pits and fissures: A 36-month, randomised controlled clinical trial. Int Dent J. 2012;62(5):251-255.

24. Fontana M, Platt JA, Eckert GJ, et al. Monitoring of sound and carious surfaces under sealants over 44 months. J Dent Res. 2014;93(11): 1070-1075.

25. Oong EM, Griffin SO, Kohn WG, Gooch BF, Caufield PW. The effect of dental sealants on bacteria levels in caries lesions: A review of the evidence. J Am Dent Assoc. 2008;139(3):271-278.

26. Martignon S, Ekstrand KR, Ellwood R. Efficacy of sealing proximal early active lesions: An 18-month clinical study evaluated by conventional and subtraction radiography. Caries Res. 2006;40(5): 382-388.

27. Paris S, Hopfenmuller W, Meyer-Lueckel H. Resin infiltration of caries lesions: An efficacy randomized trial. J Dent Res. 2010;89(8):823-826.

28. Abuchaim C, Rotta M, Grande RH, Loguercio AD, Reis A. Effectiveness of sealing active proximal caries lesions with an adhesive system: 1-year clinical evaluation. Braz Oral Res. 2010;24(3):361-367.

29. da Silveira AD, Borges BC, de Almeida Varela H, de Lima KC, Pinheiro IV. Progression of non-cavitated lesions in dentin through a nonsurgical approach: A preliminary 12-month clinical observation. Eur J Dent. 2012;6(1):34-42.

30. Bishara SE, Oonsombat C, Ajlouni R, Denehy G. The effect of saliva contamination on shear bond strength of orthodontic brackets when using a self-etch primer. Angle Orthod. 2002;72(6):554-557.

31. Bjørndal L, Larsen T, Thylstrup A. A clinical and microbiological study of deep carious lesions during stepwise excavation using long treatment intervals. Caries Res. 1997;31(6):411-417.

32. Mount GJ, Ngo H. Minimal intervention: Advanced lesions. Quintessence Int. 2000;31(9):621-629.

33. Kikwilu EN, Mandari GJ, Honkala E. Survival of Fuji IX ART fillings in permanent teeth of primary school children in Tanzania. East Afr Med J. 2001;78(8):411-413.

34. Mickenautsch S, Kopsala J, Rudolph MJ, Ogunbodede EO. Clinical evaluation of the ART approach and materials in peri-urban farm schools of the Johannesburg area. SADJ. 2000;55(7):364-368.

35. de Amorim RG, Leal SC, Frencken JE. Survival of atraumatic restorative treatment (ART) sealants and restorations: A meta-analysis. Clin Oral Investig. 2012;16(2):429-441.

36. van 't Hof MA, Frencken JE, van Palenstein Helderman WH, Holmgren CJ. The atraumatic restorative treatment (ART) approach for managing dental caries: A meta-analysis. Int Dent J. 2006;56(6):345-351.

37. Arrow P. Restorative outcomes of a minimally invasive restorative approach based on atraumatic restorative treatment to manage early childhood caries: A randomised controlled trial. Caries Res. 2016;50(1):1-8.

38. Kerkhove BC, Herman SC, Klein Al, McDonald RE. A clinical and television densitometric evaluation of the indirect pulp capping technique. J Dent Child. 1967;34(3):192-201. 
39. Magnusson BO, Sundell SO. Stepwise excavation of deep carious lesions in primary molars. J Int Assoc Dent Child. 1977;8(2):36-40.

40. Ricketts DN, Kidd EA, Innes N, Clarkson J. Complete or ultraconservative removal of decayed tissue in unfilled teeth. Cochrane Database Syst Rev. 2006;(3):CD003808. doi: 10.1002/14651858.CD003808. pub2

41. Miyashita H, Worthington HV, Qualtrough A, Plasschaert A. Pulp management for caries in adults: Maintaining pulp vitality. Cochrane Database Syst Rev. 2007;(2):CD004484. doi: 10.1002/14651858.CD004484. pub2

42. Casagrande L, Bento LW, Dalpian DM, García-Godoy F, de Araujo FB. Indirect pulp treatment in primary teeth: 4-year results. Am J Dent. 2010;23(1):34-38.

43. Bjørndal L. Indirect pulp therapy and stepwise excavation. Pediatr Dent. 2008;30(3):225-229.

44. Bjørndal L, Reit C, Bruun G, et al. Treatment of deep caries lesions in adults: Randomized clinical trials comparing stepwise vs direct complete excavation, and direct pulp capping vs partial pulpotomy. Eur J Oral Sci. 2010;118(3): 290-297.

45. Leksell E, Ridell K, Cvek M, Mejàre I. Pulp exposure after stepwise versus direct complete excavation of deep carious lesions in young posterior permanent teeth. Endod Dent Traumatol. 1996;12(4), 192-196.

46. Heinrich R, Kneist S, Künzel W. Clinical controlled study on the treatment of deep carious lesions in deciduous molars. Dtsch Zahnarztl Z. 1991;46(9):581-584.

47. Ricketts D, Lamont T, Innes NP, Kidd E, Clarkson JE. Operative caries management in adults and children. Cochrane Database Syst Rev. 2013;3:CD003808. doi: 10.1002/14651858.CD003808.pub3

48. Schwendicke F, Stolpe M, Meyer-Lueckel H, Paris S, Dörfer CE. Costeffectiveness of one- and two-step incomplete and complete excavations. J Dent Res. 2013;92(10):880-887.

49. Orhan Al, Oz FT, Orhan K. Pulp exposure occurrence and outcomes after 1-or 2-visit indirect pulp therapy vs complete caries removal in primary and permanent molars. Pediatr Dent. 2010;32(4):347-355.
50. Franzon R, Guimarães LF, Magalhães CE, Haas AN, Araujo FB. Outcomes of one-step incomplete and complete excavation in primary teeth: A 24-month randomized controlled trial. Caries Res. 2014;48(5): 376-383.

51. Maltz M, Alves LS, Jardim JJ, Moura MoS, de Oliveira EF. Incomplete caries removal in deep lesions: A 10-year prospective study. Am J Dent. 2011;24(4):211-214.

52. Maltz M, Jardim JJ, Mestrinho HD, et al. Partial removal of carious dentine: A multicenter randomized controlled trial and 18-month follow-up results. Caries Res. 2013;47(2):103-109.

53. Bjørndal L. Reentry may not be needed after partial caries removal in mainly young permanent molars with caries involving half or more of the dentin thickness. J Evid Based Dent Pract. 2013;13(2):62-63.

54. Maltz M, Oliveira EF, Fontanella V, Carminatti G. Deep caries lesions after incomplete dentine caries removal: 40-month follow-up study. Caries Res. 2007;41(6):493-496.

55. Alves LS, Fontanella V, Damo AC, Ferreira de Oliveira E, Maltz M. Qualitative and quantitative radiographic assessment of sealed carious dentin: A 10-year prospective study. Oral Surg Oral Med Oral Pathol Oral Radiol Endod. 2010;109(1):135-141.

56. Oliveira EF, Carminatti G, Fontanella V, Maltz M. The monitoring of deep caries lesions after incomplete dentine caries removal: Results after 14-18 months. Clin Oral Investig. 2006;10(2):134-139.

57. Lula E, Monteiro-Neto V, Alves CM, Ribeiro CC. Microbiological analysis after complete or partial removal of carious dentin in primary teeth: A randomized clinical trial. Caries Res. 2009;43(5):354-358.

58. Maltz M, Garcia R, Jardim JJ, et al. Randomized trial of partial vs stepwise caries removal: 3-year follow-up. J Dent Res. 2012;91(11):10261031.

59. Schwendicke F, Dörfer CE, Paris S. Incomplete caries removal: A systematic review and meta-analysis. J Dent Res. 2013;92(4):306-314.

60. Bergenholtz G, Axelsson S, Davidson T, et al. Treatment of pulps in teeth affected by deep caries - A systematic review of the literature. Singapore Dent J. 2013;34(1):1-12. 